\title{
Sorption Recovery of Palladium (II) and Platinum (IV) from Hydrochloric Acid Solutions
}

\author{
Olga N. Kononova*, Evgeniya V. Duba, \\ Nikita I. Schneider and Iliya A. Pozdnyakov \\ Siberian Federal University \\ 79 Svobodny, Krasnoyarsk, 660041, Russia
}

Received 29.01.2018, received in revised form 13.02.2018, accepted 27.02.2018

The sorption preconcentration of Pd (II) and Pt (IV) from hydrochloric acid solutions on Purolite ion exchangers with different functional groups was investigated. The initial concentrations in contacting solutions were $0.025-0.25 \mathrm{mmol} / \mathrm{L}$ for palladium and $0.25 \mathrm{mmol} / \mathrm{L}$ for platinum at the $\mathrm{HCl}$ concentrations $0.01-4.0 \mathrm{~mol} / \mathrm{L}$. It was shown that the investigated resins have high sorption ability (more than 85-95\%) to chloride complexes of noble metals. We found out that the simultaneous elution of these complexes by hydrochloric acid thiourea solution (1 mol/L in $0.5 \mathrm{M} \mathrm{HCl}$ ) is possible (to more than $80 \%)$ from anion exchangers Purolite A 111 and Purogold ${ }^{\mathrm{TM}}$ A 193.

Keywords: ion exchange, palladium, platinum, hydrochloric acid solutions.

Citation: Kononova O.N., Duba E.V., Schneider N.I., Pozdnyakov I.A. Sorption recovery of palladium (II) and platinum (IV) from hydrochloric acid solutions, J. Sib. Fed. Univ. Chem., 2018, 11(1), 6-17. DOI: 10.17516/1998-2836-0054.

(c) Siberian Federal University. All rights reserved

* Corresponding author E-mail address: cm2@bk.ru 


\title{
Сорбционное извлечение палладия (II) \\ и платины (IV) из солянокислых растворов
}

\author{
О.Н. Кононова, Е.В. Дуба, \\ Н.И. Шнайдер, И.А. Поздняков \\ Сибирский федеральный университет \\ Россия, 660041, Красноярск, пр. Свободный, 79
}

Исследовано сорбиионное концентрирование палладия (II) и платины (IV) из солянокисльх растворов на анионитах марки Pигоlite с различными функииональными группами. Исходные кониентрачии палладия и платины составляли соответственно 0.025-0.25 ммоль/л и 0.25 ммоль/л при концентрации $\mathrm{HCl}$ в контактирующих растворах 0.01-4.0 моль/л. Показана высокая сорбционная способность исследуемых ионитов по отномению $к$ хлоридным комплексам благородных металлов, проявляющаяся на уровне более 85-95\%. Установлено, что после извлечения этих комплексов возможно их совместное элюирование посредством солянокислого раствора тиомочевины (1 моль/л в $0.5 \mathrm{M} \mathrm{HCl}$ ) на уровне более $80 \%$ с анионитов Purolite A 111 u Purogold ${ }^{\mathrm{TM}}$ A 193.

Ключевые слова: ионный обмен, палладий, платина, солянокислые растворы.

\section{Introduction}

The worldwide consumption of platinum group metals (PGM) is steadily growing, and for years its application range continues to expand. Followed by that, the production of PGM became one of the most important branches in metallurgy [1,2]. The low metal content ores as well as refractory ores are getting more involved in PGM processing, including the sulfide black-shale gold ores from the northeastern regions of Russia [3, 4]. At the same time, the secondary PGM raw materials (such as spent automobile and chemical catalysts, electronic scrap, technological wastes) are more demanded as well $[5,6]$.

The recovery of noble metals from raw materials is normally carried out by precipitation or electrowinning [1, 7-10]. However, given the low concentrations of noble metals in initial industrial solutions after the breakdown, the above-mentioned methods do not result in significant recovery of PGM. Moreover, in this case the obtained solid products hinder the further processing $[1,7,8,11]$.

Fortunately, these problems can be avoided by using the sorption methods, known for their high efficiency, selectivity, environmental safety and good compatibility with PGM post-determination methods $[1,6,7,11-13]$. In a variety of sorbents, the ion exchangers with different functional groups seem promising, as they possess high exchange capacity and good kinetic properties. This makes these sorbents usable even for the preconcentration of trace amounts of PGM in presence of accompanying components $[1,5-7,11,13,14]$.

It should be noted that in most cases the ionic state of PGM industrial solutions is the chloride complexes with different stability and chemical inertness $[1,11,15,16]$. As a rule, these complexes 
are also subjected to hydrolysis and aquation - the factor that makes the system more complicated $[1$, $15,16]$.

Since palladium and platinum are associated in primary and secondary raw materials, and also pass simultaneously into solution after the processing, the recovery of Pd and Pt on selective ion exchangers is a matter of academic and practical interest. In this case some researchers use strong base anion exchangers for recovery of chloride complexes of Pd and Pt because their sorption is carried out from strong acidic media $(2-6 \mathrm{M} \mathrm{HCl})[6,11,17]$. However, when processing the secondary PGM sources, it often results in obtaining of hydrochloric acid solutions with lower acidity $(0.01 \mathrm{~mol} / \mathrm{L}$ and less). In turn, it requires using the weak base anion exchangers or chelating sorbents for the recovery of palladium and platinum from such kind of solutions. The sorption ability of these anion exchangers facilitates the extraction of complex ions of noble metals not only through ion exchange mechanism, but also by means of additional complex formation between the nitrogen atoms of functional groups and atoms of the recovered metals [18].

Moreover, it should be noted that platinum and palladium complexes in real industrial hydrochloric acid solutions are often accompanied by iron and non-ferrous metal ions that complicate the isolation of noble metals. These real industrial solutions differ from each other by the composition and concentrations of components, stipulated by the differences in the breakdown methods for primary or secondary sources of mineral materials. Consequently, this requires various approaches to the recovery of noble metals, adjusted to the specific types of real solutions. Previously we have investigated the recovery of platinum and palladium from refractory sulfide black-shale ores [4], when the metals were successfully recovered with selective ion exchangers after the breakdown of ores. The similar problems were successfully solved by the authors [6-8].

The present work is devoted to the sorption recovery of palladium and platinum on various ions exchangers from model hydrochloric acid solutions. We intend to develop this investigation further by studying the effect of accompanying ions on the recovery of these noble metals.

\section{Materials and methods}

In the present work we investigate some anion exchangers synthesized by Purolite Int. Ltd. The resins are based on styrene and divinylbenzene (DVB), except the sorbent Purolite S 985, which is based on polyacrylate and DVB. Their physical-chemical characteristics are presented in Table 1. As

Table 1. Physical-chemical properties of the anion exchangers investigated

\begin{tabular}{|c|c|c|c|c|}
\hline Trade name & Exchanger type & Functional groups ${ }^{*}$ & $\begin{array}{l}\text { Exchange capacity } \\
\text { in the chloride } \\
\text { form, } \mathrm{mmol} / \mathrm{g}\end{array}$ & Swelling grade, $\%$ \\
\hline Purolite A 500 & Strong base & QAB & 1.2 & 20 \\
\hline Purogold ${ }^{\mathrm{TM}} \mathrm{S} 992$ & Complexing resin & Mixed amines & 4.4 & 20 \\
\hline Purolite S 985 & Complexing resin & Polyamines & 2.3 & 20 \\
\hline Purolite A 111 & Weak base & TAG & 1.7 & 40 \\
\hline Purogold ${ }^{\mathrm{TM}}$ A 193 & Intermediate base & TAG, QAB & 3.8 & 22 \\
\hline
\end{tabular}

"QAB - quaternary ammonia base; TAG - tertiary amino-groups. 
follows from this Table, the studied resins possess various functional groups and, therefore, different basicity. Their physical structure belongs to the macroporous type. Prior to the experiment, the ion exchangers were prepared according to the conventional methods and converted into the initial chloride form [19].

The initial working palladium solution with concentration $5.55 \mathrm{mmol} / \mathrm{L}$ and platinum solution with concentration $102.6 \mathrm{mmol} / \mathrm{L}$ were prepared by dissolution of accurately weighed quantities of $\mathrm{PdCl}_{2} \cdot 2 \mathrm{H}_{2} \mathrm{O}$ and $\mathrm{H}_{2} \mathrm{PtCl}_{6} \cdot 6 \mathrm{H}_{2} \mathrm{O}$ in low volume of concentrated $\mathrm{HCl}$. Then the solutions were placed into a graduated flask $(50 \mathrm{~mL})$ and brought to the flask's mark with distilled water [15, 20].

We have used in the present work the freshly prepared solutions of palladium with concentrations 0.025 and $0.25 \mathrm{mmol} / \mathrm{L}$ and of platinum with concentration $0.25 \mathrm{mmol} / \mathrm{L}$. The $\mathrm{HCl}$ concentrations in the contacting solutions were $0.01,2.0$ and $4.0 \mathrm{~mol} / \mathrm{L}$. The concentrations and acidity of the investigated solutions were chosen with an intention to make the experimental conditions closer to real industrial conditions.

The concentrations of palladium and platinum in solutions were determined by spectrophotometrical method with nitroso-R-salt and tin (II) chloride, respectively [15, 20, 21]. The ionic state of noble metals in the solutions was confirmed by absorption spectra at 190-700 nm.

The sorption of noble metals was studied under batch experiment conditions: resin mass $-0.1 \mathrm{~g}$; volume of contacting solution $-10.0 \mathrm{~mL}$. The equilibrium time determined by special test was $24 \mathrm{~h}$.

The sorption ability of the anion exchangers investigated was estimated by means of the recovery degree (R, \%), distribution coefficient (D) and separation coefficient (S), calculated as follows:

$$
\begin{aligned}
& R=\frac{C_{0}-C_{e q}}{C_{0}} \cdot 100 \%, \\
& D=\frac{W E C}{C_{e q}}, \\
& S=\frac{D_{P d}}{D_{P t}},
\end{aligned}
$$

where $C_{0}$ and $C_{e q}$ are the initial and equilibrium molar concentrations of palladium and platinum solutions, respectively; $W E C(\mathrm{mmol} / \mathrm{g})$ is working exchange capacity of the resins towards the recovered ions. The latter was calculated from the equation:

$$
W E C=\frac{\left(C_{0}-C_{e q}\right) \cdot V}{q},
$$

where $V(\mathrm{~L})$ is volume of the contacting solution and $q(\mathrm{~g})$ is the resin quantity.

The sorption isotherms were plotted by varying the molar ratio of resins to the amount of Pd and $\mathrm{Pt}$ in contacting solution [22, 23]. Then, using the obtained curves, the apparent constants of ion exchange equilibrium were calculated according to the law of mass action [22, 23].

The elution of palladium and platinum after their simultaneous sorption was carried out under dynamic conditions in glass columns $(\sim 1 \mathrm{~cm}$ diameter and $\sim 20 \mathrm{~cm}$ height). First, the air-dryed resin quantities were placed into hydrochloric acid solution $(2.0$ or $4.0 \mathrm{~mol} / \mathrm{L})$ and left for $30 \mathrm{~min}$ for swelling. Then the swelled resins were placed into the column (bed height was $1.5 \mathrm{~cm}$ ) and $100.0 \mathrm{~mL}$ of palladium and platinum solutions were passed through the column. The flow rate was $1 \mathrm{~mL} / \mathrm{min}$. 
The separate solution portions of the filtrate $(5.0-10.0 \mathrm{~mL})$ were collected. After that the contents of palladium and platinum were determined in each portion. After the saturation of resin with the sorbed ions, the column was washed with a low volume $(\sim 10 \mathrm{~mL})$ of $0.5 \mathrm{M} \mathrm{HCl}$ and then the eluent was passed through the column, to achieve Pd and Pt recovery. The hydrochloric acid thiourea solution $(1 \mathrm{M}$ in $0.5 \mathrm{M} \mathrm{HCl})$ was taken as an elution agent. The separate filtrate portions $(5.0 \mathrm{~mL})$ were collected and the concentrations of $\mathrm{Pd}$ and $\mathrm{Pt}$ were determined by a spectrophotometrical method according to intrinsic colors of the metal complexes with thiourea [20,21]. All the reagents used were of analytical purification grade.

The results obtained were subjected to statistical processing according to conventional procedures $[24,25]$. The average experimental error for 3 parallel runs and at confidence level of 0.95 was less than $6 \%$.

\section{Results and discussion}

The complexation of palladium and platinum in chloride and hydrochloric acid solutions is investigated in detail $[1,15,16,26]$. It was found out that the ionic state of PGM in such solutions depends on their acidity as well as on concentration of chloride ions. Depending on these factors, the various aqua and hydroxo-chloride complexes with different stability and kinetic inertness can be formed in aqueous solutions.

Palladium (II) complexes $\left[\mathrm{PdCl}_{4}\right]^{2-}$ predominate in solutions where $\mathrm{HCl}$ concentration exceeds $1 \mathrm{~mol} / \mathrm{L}$. With the decrease in acidity, these complexes are subjected to aquation under the formation of forms $\left[\mathrm{Pd}\left(\mathrm{H}_{2} \mathrm{O}\right)_{\mathrm{n}} \mathrm{Cl}_{\mathrm{n}-4}\right]^{\mathrm{n}-2}$, where $\mathrm{n}$ changes from 0 to $3[1,20,26]$. The cumulative stability constant of $\left[\mathrm{PdCl}_{4}\right]^{2-}$ ions is estimated as $\log \beta_{4}=11.12-12.24[1,20]$. It should be noted that the chloride complexes of palladium (IV) are stable only in presence of oxidants. That is why solely palladium (II) complexes exist in hydrochloric acid solutions [1,20].

$\left[\mathrm{PtCl}_{6}\right]^{2-}$ predominate in solutions with $\mathrm{HCl}$ concentration $3 \mathrm{~mol} / \mathrm{L}$ and more. The dilution of these solutions and increase in their $\mathrm{pH}$ value leads to the formation of aqua and hydroxo-complexes in the system, which co-exist in different proportions $[1,15,20,26]$. The chloride complexes of platinum (IV) are very stable and kinetically inert. The cumulative stability constant of $\left[\mathrm{PtCl}_{6}\right]^{2-}$ ions is $\log \beta_{6}=33.9[1,20]$.

As it was mentioned above, in the present work we have investigated the sorption recovery of noble metals from strong acidic solutions (with hydrochloric acid concentrations 4.0 and $2.0 \mathrm{~mol} / \mathrm{L}$ ) and from weak acidic solutions (with $\mathrm{HCl}$ concentration $0.01 \mathrm{~mol} / \mathrm{L}$ ) as well. We have recorded the absorption spectra of freshly prepared palladium solutions in $2 \mathrm{M}$ and $0.01 \mathrm{M} \mathrm{HCl}$ and revealed that both spectra had absorption maximum at $325 \mathrm{~nm}$. These indicates the presence of $\left[\mathrm{PdCl}_{4}\right]^{2-}$ ions, in full compliance with the literature data $[1,20,26]$.

The spectrum of freshly prepared platinum solution in $2 \mathrm{M} \mathrm{HCl}$ had absorption maximum at $251 \mathrm{~nm}$, which corresponds to $\left[\mathrm{PtCl}_{6}\right]^{2-}$. The spectrum of freshly prepared platinum solution in 0.01 $\mathrm{M} \mathrm{HCl}$ had two absorption maxima, at $251 \mathrm{~nm}$ and $355 \mathrm{~nm}$, pointing out to the presence of complexes $\left[\mathrm{PtCl}_{6}\right]^{2-}$ and $\left[\mathrm{Pt}(\mathrm{OH}) \mathrm{Cl}_{5}\right]^{2-}$, respectively. Again, all these results are in full compliance with the literature $[1,20,26]$.

Therefore, the composition of contacting palladium solutions is the same in strong and weak acidic media, whereas platinum solutions have different composition depending on acidity of solution. 
Our further studies were devoted to the sorption properties of the ion exchangers during the recovery of chloride complexes of $\mathrm{Pd}$ (II) and Pt (IV) from individual solutions in dependence of $\mathrm{HCl}$ concentration. The results are presented in Tables 2 and 3.

It can be seen from these data that all the investigated anion exchangers reveal high sorption ability to the recovered chloride complexes of noble metals, regardless of their functional groups. With the decrease in $\mathrm{HCl}$ concentration in contacting solution, a slight increase in sorption parameters takes place because of reduction of competing effect of chloride ions.

After that we have investigated the sorption preconcentration of noble metals at their simultaneous presence in $\mathrm{HCl}$ solutions. The results are presented in Tables 4 and 5.

These data also demonstrate high sorption ability of the investigated resins, although there is a slight decrease in recovery degree of palladium (II) in the presence of platinum (IV) - in comparison with its sorption from individual solutions (Table 2). This can be explained by several

Table 2. Sorption of $\mathrm{Pd}$ (II) from individual hydrochloric acid solutions $\left(\mathrm{C}_{0}(\mathrm{Pd})=0.025 \mathrm{mmol} / \mathrm{L}\right)$

\begin{tabular}{|l|c|c|c|c|}
\hline \multirow{2}{*}{ Trade name } & \multirow{2}{*}{ Parameter } & \multicolumn{3}{|c|}{$\mathrm{C}_{0}(\mathrm{HCl}), \mathrm{mol} / \mathrm{L}$} \\
\cline { 2 - 5 } & & 4.0 & 2.0 & 0.01 \\
\hline \multirow{2}{*}{ Purolite A 500 } & $\lg \mathrm{D}$ & $3.66 \pm 0.22$ & $3.51 \pm 0.21$ & $3.67 \pm 0.18$ \\
\cline { 2 - 5 } & $\mathrm{R}, \%$ & $93 \pm 5$ & $94 \pm 5$ & $95 \pm 5$ \\
\hline \multirow{2}{*}{ Purogold $\mathrm{TM}$ S 992 } & $\lg \mathrm{D}$ & $2.03 \pm 0.11$ & $2.61 \pm 0.16$ & $2.68 \pm 0.16$ \\
\cline { 2 - 5 } & $\mathrm{R}, \%$ & $92 \pm 5$ & $95 \pm 5$ & $95 \pm 5$ \\
\hline \multirow{2}{*}{ Purolite S 985 } & $\lg \mathrm{D}$ & $2.29 \pm 0.12$ & $2.59 \pm 0.13$ & $2.58 \pm 0.13$ \\
\cline { 2 - 5 } & $\mathrm{R}, \%$ & $95 \pm 5$ & $95 \pm 5$ & $95 \pm 5$ \\
\hline \multirow{2}{*}{ Purolite A 111 } & $\lg \mathrm{D}$ & $2.18 \pm 0.13$ & $2.42 \pm 0.15$ & $2.44 \pm 0.15$ \\
\hline \multirow{2}{*}{ PurogoldTM A 193 } & $\mathrm{R}, \%$ & $93 \pm 5$ & $94 \pm 5$ & $95 \pm 5$ \\
\cline { 2 - 5 } & $\mathrm{lg} \mathrm{D}$ & $1.81 \pm 0.11$ & $2.03 \pm 0.12$ & $2.56 \pm 0.15$ \\
\hline
\end{tabular}

Table 3. Sorption of Pt (IV) from individual hydrochloric acid solutions $\left(\mathrm{C}_{0}(\mathrm{Pt})=0.25 \mathrm{mmol} / \mathrm{L}\right)$

\begin{tabular}{|l|c|c|c|c|}
\hline \multirow{2}{*}{ Trade name } & \multirow{2}{*}{ Parameter } & \multicolumn{3}{|c|}{$\mathrm{C}_{0}(\mathrm{HCl}), \mathrm{mol} / \mathrm{L}$} \\
\cline { 2 - 4 } & & 4.0 & 2.0 & 0.01 \\
\hline \multirow{2}{*}{ Purolite A 500 } & $\lg \mathrm{D}$ & $2.37 \pm 0.12$ & $2.59 \pm 0.16$ & $2.59 \pm 0.16$ \\
\cline { 2 - 5 } & $\mathrm{R}, \%$ & $92 \pm 5$ & $94 \pm 5$ & $94 \pm 5$ \\
\hline \multirow{2}{*}{ Purogold $\mathrm{TM}$ S 992 } & $\lg \mathrm{D}$ & $2.01 \pm 0.12$ & $2.71 \pm 0.14$ & $2.84 \pm 0.14$ \\
\cline { 2 - 5 } & $\mathrm{R}, \%$ & $92 \pm 5$ & $95 \pm 5$ & $95 \pm 5$ \\
\hline \multirow{2}{*}{ Purolite S 985 } & $\lg \mathrm{D}$ & $1.88 \pm 0.11$ & $2.18 \pm 0.13$ & $3.02 \pm 0.15$ \\
\cline { 2 - 5 } & $\mathrm{R}, \%$ & $88 \pm 5$ & $94 \pm 5$ & $95 \pm 5$ \\
\hline \multirow{2}{*}{ Purolite A 111 } & $\lg \mathrm{D}$ & $1.97 \pm 0.12$ & $3.05 \pm 0.18$ & $3.09 \pm 0.19$ \\
\hline \multirow{2}{*}{ Purogold } & $\mathrm{R}, \%$ & $93 \pm 5$ & $94 \pm 5$ & $95 \pm 5$ \\
\cline { 2 - 5 } & $\lg \mathrm{D}$ & $2.48 \pm 0.15$ & $2.53 \pm 0.15$ & $2.55 \pm 0.15$ \\
\hline
\end{tabular}


Table 4. Sorption of $\mathrm{Pd}(\mathrm{II})$ in presence of $\mathrm{Pt}(\mathrm{IV})$ in hydrochloric acid solutions $\left(\mathrm{C}_{0}(\mathrm{Pd})=0.025 \mathrm{mmol} / \mathrm{L}\right.$; $\left.\mathrm{C}_{0}(\mathrm{Pt})=0.25 \mathrm{mmol} / \mathrm{L}\right)$

\begin{tabular}{|l|c|c|c|c|}
\hline \multirow{2}{*}{ Trade name } & \multirow{2}{*}{ Parameter } & \multicolumn{3}{|c|}{$\mathrm{C}_{0}(\mathrm{HCl}), \mathrm{mol} / \mathrm{L}$} \\
\cline { 2 - 4 } & & 4.0 & 2.0 & 0.01 \\
\hline \multirow{2}{*}{ Purolite A 500 } & $\lg \mathrm{D}$ & $1.91 \pm 0.11$ & $1.89 \pm 0.11$ & $1.98 \pm 0.12$ \\
\cline { 2 - 5 } & $\mathrm{R}, \%$ & $89 \pm 5$ & $91 \pm 5$ & $95 \pm 5$ \\
\hline \multirow{2}{*}{ Purogold } & $\lg \mathrm{D}$ & $1.68 \pm 0.11$ & $1.81 \pm 0.11$ & $1.82 \pm 0.11$ \\
\hline \multirow{2}{*}{ Purolite S 985 } & $\mathrm{R}, \%$ & $83 \pm 4$ & $87 \pm 5$ & $89 \pm 5$ \\
\cline { 2 - 5 } & $\lg \mathrm{D}$ & $1.76 \pm 0.11$ & $1.64 \pm 0.10$ & $1.68 \pm 0.11$ \\
\hline \multirow{2}{*}{ Purolite A 111 } & $\mathrm{R}, \%$ & $85 \pm 5$ & $82 \pm 4$ & $83 \pm 4$ \\
\cline { 2 - 5 } & $\lg \mathrm{D}$ & $1.82 \pm 0.11$ & $1.56 \pm 0.10$ & $88 \pm 5$ \\
\hline \multirow{2}{*}{ Purogold } & $\mathrm{R}, \%$ & $87 \pm 5$ & $78 \pm 5$ & $1.64 \pm 0.10$ \\
\hline
\end{tabular}

Table 5. Sorption of $\mathrm{Pt}(\mathrm{IV})$ in presence of $\mathrm{Pd}$ (II) in hydrochloric acid solutions $\left(\mathrm{C}_{0}(\mathrm{Pt})=0.25 \mathrm{mmol} / \mathrm{L}\right.$; $\left.\mathrm{C}_{0}(\mathrm{Pd})=0.025 \mathrm{mmol} / \mathrm{L}\right)$

\begin{tabular}{|c|c|c|c|c|}
\hline \multirow{2}{*}{ Trade name } & \multirow{2}{*}{ Parameter } & \multicolumn{3}{|c|}{$\mathrm{C}_{0}(\mathrm{HCl}), \mathrm{mol} / \mathrm{L}$} \\
\cline { 2 - 4 } & & 4.0 & 2.0 & 0.01 \\
\hline \multirow{2}{*}{ Purolite A 500 } & $\lg \mathrm{D}$ & $2.60 \pm 0.16$ & $2.81 \pm 0.17$ & $2.77 \pm 0.17$ \\
\cline { 2 - 5 } & $\mathrm{R}, \%$ & $95 \pm 5$ & $95 \pm 5$ & $95 \pm 5$ \\
\hline \multirow{2}{*}{ Purogold } & $\lg \mathrm{D}$ & $2.27 \pm 0.14$ & $2.40 \pm 0.14$ & $2.62 \pm 0.16$ \\
\hline Purolite S 985 & $\mathrm{R}, \%$ & $95 \pm 5$ & $95 \pm 5$ & $95 \pm 5$ \\
\cline { 2 - 5 } & $\lg \mathrm{D}$ & $2.15 \pm 0.13$ & $2.24 \pm 0.13$ & $2.95 \pm 0.18$ \\
\hline Purolite A 111 & $\mathrm{R}, \%$ & $93 \pm 5$ & $95 \pm 5$ & $95 \pm 5$ \\
\cline { 2 - 5 } & $\lg \mathrm{D}$ & $2.37 \pm 0.14$ & $2.50 \pm 0.15$ & $2.80 \pm 0.17$ \\
\hline Purogold & $\mathrm{R}, \%$ & $95 \pm 5$ & $95 \pm 5$ & $95 \pm 5$ \\
\cline { 2 - 5 } & $\lg \mathrm{D}$ & $2.29 \pm 0.14$ & $2.58 \pm 0.15$ & $2.89 \pm 0.17$ \\
\hline
\end{tabular}

reasons. First, this is the result of the reciprocal influence of chloride complexes of the recovered noble metals. Second, it is explained by higher selectivity of the anion exchangers towards platinum (IV) complexes, that are more stable compared to palladium (II) complexes [1, 20]. The general theory of selectivity of ion exchange states that an ion exchanger usually is more selective to the complex ion with higher stability [22, 27, 28]. Noteworthy, the acidity of contacting solutions is practically not important for sorption preconcentration of the recovered complexes at their simultaneous presence.

We have calculated the separation coefficients for palladium (II) and platinum (IV), which are represented in Table 6. It can be seen from this Table that these values point out to the difficulties for the separation of chloride complexes of palladium and platinum due to the high selectivity of investigated resins. 
We have studied the ion exchange equilibriums for the recovery of chloride complexes of Pd (II) and Pt (IV) by obtaining sorption isotherms. These curves are shown in Figures 1 and 2 for anion exchangers Purogold ${ }^{\mathrm{TM}}$ A 193 and Purolite A 111. It can be seen that the curves are convex in general, i.e. the anion exchangers are selective towards the recovered noble metals [18, 22, 23]. The isotherms were used to calculate the apparent constants of ion exchange equilibrium. The values are presented in Table 7.

Table 6. Separation coefficients of Pd (II) and Pt (IV) during their sorption from hydrochloric acid solutions $\left(\mathrm{C}_{0}(\mathrm{Pd})=\mathrm{C}_{0}(\mathrm{Pt})=0.25 \mathrm{mmol} / \mathrm{L}\right)$

\begin{tabular}{|c|c|c|c|}
\hline \multirow{2}{*}{ Trade name } & \multicolumn{3}{|c|}{$\mathrm{C}_{0}(\mathrm{HCl}), \mathrm{mol} / \mathrm{L}$} \\
\cline { 2 - 4 } & 4.0 & 2.0 & 0.01 \\
\hline Purolite A 500 & 0.20 & 0.06 & 0.11 \\
\hline Purogold & 0.19 & 0.11 \\
\hline Purolite S 995 & 0.35 & 0.26 & 0.05 \\
\hline Purolite A 111 & 0.31 & 0.11 & 0.12 \\
\hline Purogold $^{\mathrm{TM}}$ A 193 & 0.27 & 0.09 & 0.06 \\
\hline
\end{tabular}
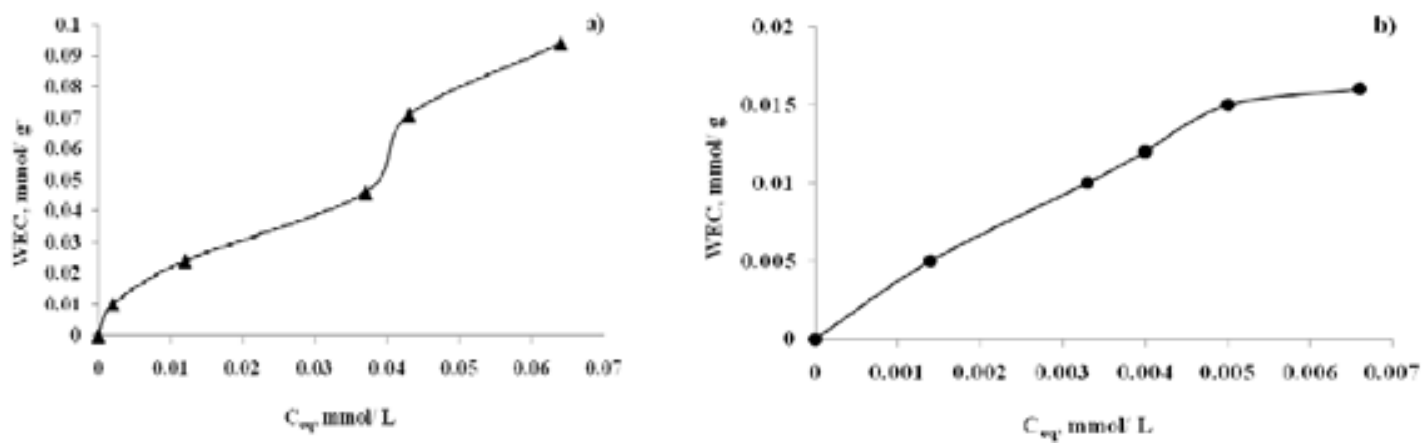

Fig. 1. Sorption isotherms of chloride complexes of Pd (II) (a) and Pt (IV) (b) from individual solutions on anion exchanger Purogold ${ }^{\mathrm{TM}}$ A $193\left(\mathrm{C}_{0}(\mathrm{HCl})=2.0 \mathrm{~mol} / \mathrm{L}\right)$
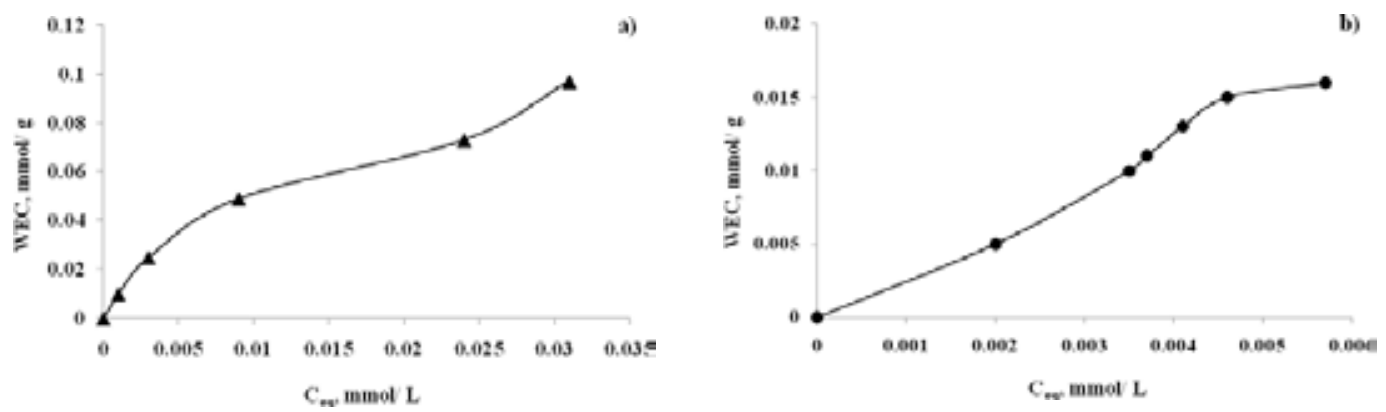

Fig. 2. Sorption isotherms of chloride complexes of $\mathrm{Pd}$ (II) in presence of $\mathrm{Pt}$ (IV) (a) and of Pt (IV) in presence of $\mathrm{Pd}(\mathrm{II})(\mathrm{b})$ on anion exchanger Purolite A $111\left(\mathrm{C}_{0}(\mathrm{HCl})=2.0 \mathrm{~mol} / \mathrm{L}\right)$ 
Table 7. Apparent constants of sorption equilibrium during recovery of Pd (II) and Pt (IV) from individual solutions and at simultaneous presence $\left(\mathrm{C}_{0}(\mathrm{HCl})=2.0 \mathrm{~mol} / \mathrm{L}\right)$

\begin{tabular}{|c|c|c|c|c|}
\hline \multirow{2}{*}{ Trade name } & \multicolumn{2}{|c|}{ Sorption from individual solutions } & \multicolumn{2}{c|}{ Sorption at simultaneous presence } \\
\cline { 2 - 5 } & $\mathrm{Pd}(\mathrm{II})$ & $\operatorname{Pt}(\mathrm{IV})$ & $\mathrm{Pd}(\mathrm{II})$ & $\mathrm{Pt}(\mathrm{IV})$ \\
\hline Purolite A 500 & 0.54 & 0.31 & 0.47 & 0.47 \\
\hline Purogold $\mathrm{TM}$ S 992 & 0.33 & 0.12 & 0.48 & 0.35 \\
\hline Purolite S 985 & 0.65 & 0.28 & 0.58 & 0.22 \\
\hline Purolite A 111 & 0.16 & 0.14 & 0.86 & 0.42 \\
\hline Purogold & 0.18 & 0.43 & 0.21 \\
\hline
\end{tabular}

It is known that these constants are quantitative characteristics of the ion exchangers affinity to the recovered ions $[22,23]$. Therefore, the obtained data prove the selectivity of ion exchangers. This conclusion is consistent with the data on sorption of Pd (II) and Pt (IV) from individual hydrochloric acid solutions as well as at their simultaneous presence in these solutions (Tables 2-4).

Since we have revealed the high selectivity of the ion exchangers investigated towards the recovered chloride complexes of Pd (II) and Pt (IV), it was a matter of practical interest to study of the desorption of these ions under the dynamic conditions. It is known that high selectivity of ion exchangers to the recovered components means that desorption of these components would be more problematic [18, 22, 23, 27].

It was mentioned above that we used hydrochloric acid thiourea solution as a desorption agent. The advantage of this eluent is in its ability to form the positively charged complexes $\left[\operatorname{Pd}\left(\mathrm{SCN}_{2} \mathrm{H}_{4}\right)_{4}\right]^{2+}$ and $\left[\mathrm{Pt}\left(\mathrm{SCN}_{2} \mathrm{H}_{4}\right)_{4}\right]^{2+}$, the stability of which is much higher than that one of the chloride complexes of palladium and platinum $\left(\log \beta_{4}>40-43\right)$ [20].

The elution curves for anion exchanger Purogold ${ }^{\mathrm{TM}}$ A 193 are represented in Fig. 3. According to these data, the practically complete elution of palladium and platinum is achieved after passing of $50-60 \mathrm{~mL}$ of thiourea solution.

Table 8 contains the data on palladium and platinum desorption from the anion exchangers investigated after the simultaneous sorption of noble metals from $\mathrm{HCl}$ solutions with concentrations

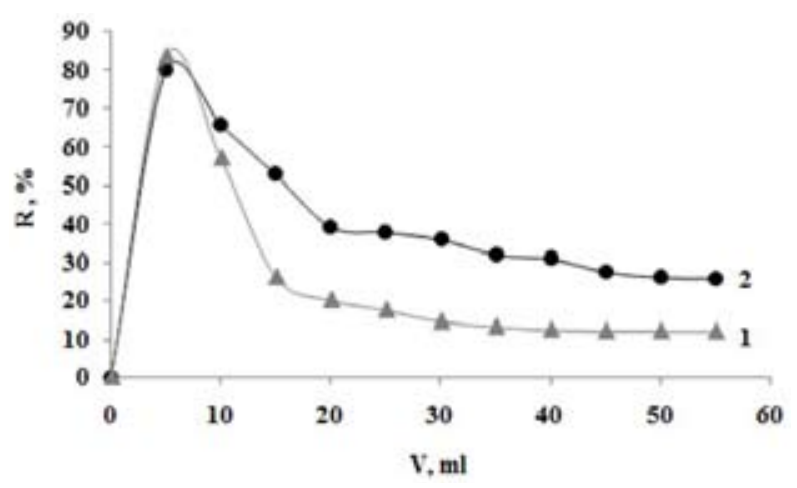

Fig. 3. Elution curves for desorption of $\mathrm{Pd}(1)$ and $\mathrm{Pt}$ (2) from anion exchanger Purogold ${ }^{\mathrm{TM}} \mathrm{A} 193$ by hydrochloric acid thiourea solution. Sorption conditions: $\mathrm{C}_{0}(\mathrm{HCl})=2.0 \mathrm{~mol} / \mathrm{L} ; \mathrm{C}_{0}(\mathrm{Pd})=\mathrm{C}_{0}(\mathrm{Pt})=0.25 \mathrm{mmol} / \mathrm{L}$ 
Table 8. Elution of Pd and Pt by thiourea solution $(1 \mathrm{~mol} / \mathrm{L}$ in $0.5 \mathrm{M} \mathrm{HCl})$. Sorption conditions: $\mathrm{C}_{0}(\mathrm{Pd})=\mathrm{C}_{0}(\mathrm{Pt})=$ $=0.25 \mathrm{mmol} / \mathrm{L}$

\begin{tabular}{|c|c|c|c|c|}
\hline \multirow{3}{*}{ Trade name } & \multicolumn{4}{|c|}{ Desorption degree, $\%$ for } \\
\hline & \multicolumn{2}{|c|}{ Pd recovery from } & \multicolumn{2}{|c|}{ Pt recovery from } \\
\hline & $2 \mathrm{M} \mathrm{HCl}$ & $4 \mathrm{M} \mathrm{HCl}$ & $2 \mathrm{M} \mathrm{HCl}$ & $4 \mathrm{M} \mathrm{HCl}$ \\
\hline Purolite A 500 & 69 & 66 & 84 & 85 \\
\hline Purogold ${ }^{\mathrm{TM}}$ S 992 & 54 & 54 & 77 & 83 \\
\hline Purolite A 111 & 87 & 86 & 98 & 98 \\
\hline PurogoldTM A 193 & 84 & 87 & 80 & 88 \\
\hline
\end{tabular}

4.0 and $2.0 \mathrm{~mol} / \mathrm{L}$. It can be seen from these results that desorption of noble metals from the resins proceeds in different way. Moreover, the recovery degree of platinum is greater than that of palladium. The best results were obtained for weak base anion exchanger Purolite A 111. It should be noted that after $24 \mathrm{~h}$, desorption of palladium and platinum complexes is on the level of $95-100 \%$ for all the ion exchangers investigated.

We have pointed above to the probable difficulties in palladium and platinum separation, originating from the low values of their separation coefficients (Table 6) and high selectivity of the sorbents investigated. This fact is confirmed by the desorption data, in the case of simultaneous elution of both noble metals. However, the positively charged Pd and Pt thiourea complexes can be successfully separated after their simultaneous isolation by electrolysis - an industrial method [1, 20, 29]. Therefore, the anion exchangers Purolite A 111 and Purogold ${ }^{\mathrm{TM}}$ A 193 can be recommended for use in technological schemes for palladium and platinum recovery from hydrochloric acid solutions.

\section{Conclusions}

The investigation revealed the high sorption ability of studied ion exchangers during their recovery of chloride complexes of palladium (II) and platinum (IV). The high selectivity of the resins makes it impossible to separate the investigated noble metals - neither during sorption, nor during elution. However, the simultaneous desorption of Pd and Pt by hydrochloric acid thiourea solution does not reduce the practical significance of the present work, as the separation of noble metals from thiourea complexes can be achieved by electrolysis - the widespread procedure for the plant conditions. That is why we recommend anion exchangers Purolite A 111 and Purogold ${ }^{\mathrm{TM}}$ A 193 for technological schemes for the recovery of palladium and platinum from various in $\mathrm{HCl}$ concentration solutions.

\section{Acknowledgements}

The authors are grateful to the Moscow office of the Purolite Int. Ltd. and personally to M.A. Mikhaylenko for the samples of anion exchangers kindly provided for investigation. 


\section{References}

1. Золотов Ю.А., Варшал Г.М., Иванов В.М. Аналитическая химия металлов платиновой группы. М.: Эдиториал Пресс, 2003. 592 с. [Zolotov Y.A., Varshal G.M., Ivanov V.M. Analytical chemistry of platinum group metals. Moscow: Editorial URSS, 2003. 592 p. (In Russ.)]

2. Корнеев С.И. Международный обзор рынка цветных металлов. Цветные Металльь 2016. T. 6 , C. 4 - 6. [Korneev S.I. International review of the nonferrous metals market. Tsvetnye Metally 2016. Vol. 6, P. 4 - 6. (In Russ.)]

3. Ставский А.П. Минеральное сырьё от недр земли до рынка. Благородные металлы и алмазы. Золото, серебро, платиновые металлы и алмазы. М.: Научный Мир, 2011. 400 c. [Stavskiy A.P. Mineral raw materials: from bowels of the earth to market. Noble metals and diamonds. Gold, silver, platinum group metals and diamonds. Moscow: Nauchny Mir, 2011. 400 p. (In Russ.)]

4. Kononova O.N., Patrushev V.V., Kononov Y.S. Recovery of noble metals from refractory sulfide black-shale ores. Hydrometallurgy 2014.Vol. 144-145, P. 156 - 162.

5. Yin C.Y., Nikoloski A.N., Wang M.W. Microfluidic solvent extraction of platinum and palladium from a chloride leach solution using Alanine 336. Mineral Engineering 2013.Vol. 45, P.18 - 21 .

6. Nikoloski A.N., Ang K.L. Review on the application ion exchange resins for the recovery of platinum-group metals from hydrochloric acid solutions. Mineral Processing and Extractive Metallurgy Review 2014. Vol. 35, P. 369 - 389.

7. Палант А.А., Левчук О.М., Брыкин К.А. Сорбционное извлечение ионов платины из промышленных кислых растворов, содержащих высокие содержания железа. Цветные Металль 2012. Т. 5, С. 42 - 46. [Palant A.A., Levchyuk O.M., Brykin K.A. Sorption recovery of platinum ions from industrial acidic solutions containing high quantities of iron. Tsvetnye Metally 2012. Vol. 5, P. 42 - 46. (In Russ.)]

8. Angelidis T.N., Skouraki E. Preliminary studies of platinum dissolution from a spent industrial catalyst. Applied Catalalysis A: general 1996. Vol. 142, P. 387 - 392.

9. Чернышова О.В., Дробот Д.В., Чернышов В.И. Новые электрохимические процессы в технологии палладия. Российский химический журнал 2006. Т. 50 (4), С. 13 - 18. [Chernyshova O.V., Drobot D.V., Chernyshov V.I. Novel electrochemical processes in palladium technology. Russian Chemical. Journal 2006. Vol. L (4), P. 13 - 18. (In Russ.)]

10. Tatarnikov A.V., Sokolovskaya I.V., Shneerson Y.M., Lapin A.Y., Goncharov P.M. Treatment of platinum flotation products. Platinum Metals Review 2004. Vol.48, P. 125 - 132.

11. Nikoloski A.N., Ang K.L., Li D. Recovery of platinum and rhodium from acidic chloride leach solution using ion exchange resins. Hydrometallurgy 2015. Vol. 152, P. 20 - 32.

12. Miroshnichenko A.A., Sorption recovery of platinum metals from compound solutions. Procedia Engineering 2016. Vol. 152, P. 8 - 12.

13. Hubicki Z., Wawrzkiewicz M., Wolowicz A. Application of ion exchange methods in recovery of Pd (II) ions - a review. Chemistry Analytics 2008. Vol. 53, P. $759-784$.

14. Raju B, Kumar J.R., Lee J.Y., Kantam M.L. Separation of platinum and rhodium from chloride solutions containing aluminum, magnesium and iron using solvent extraction and precipitation methods. Journal of Hazardous Materials 2012. Vol. 227-228, P. 142 - 147. 
15. Beamish F.E. The analytical chemistry of the noble metals. Oxford, London, Edinburgh, New York, Toronto, Paris: Pergamon Press, 1966. 702 p.

16. Cotton F.A.,Wilkinson C. Advanced inorganic chemistry. A comprehensive text. New York: Wiley and Sons, 1969. $410 \mathrm{p}$.

17. Wolowicz A., Hubicki Z. Sorption behavior of Dowex PSR-2 and Dowex PSR-3 resins of different structures for metal (II) removal. Solvent Extraction and Ion Exchange 2016. Vol. 34 (4), P. $375-397$.

18. Салдадзе К.М.. Копылова-Валова В.Д. Комплексообразующие иониты. М.: Химия, 1980. 356 c. [Saldadze K.M., Kopylova-Valova V.D. Complex-forming ion exchangers. Moscow: Khimiya, 1980, 356 p. (In Russ.)]

19. Marhol M. Ion exchangers in analytical chemistry. Their properties and use in inorganic chemistry. Prague: Academia, 1982, 585 p.

20. Гинзбург С.И.. Езерская Н.А., Прокофьева И.В., Федорова Н.В., Шленская В.И., Бельский Н.К. Аналитическая химия платиновых металлов. М.: Наука, 1972. 615 с. [Ginzburg S.I., Ezerskaya N.A., Prokofieva I.V., Feodorova N.V., Shlenskaya V.I., Belskiy N.K.. Analytical chemistry of platinum group metals. Moscow: Nauka, 1972. 615 p. (In Russ.)]

21. Umland F., Janssen A., Thierig D., Wünsch G. Theorie und praktische Anwendung von Komplexbildnern. Frankfurt/Main: Akademische Verlagsgesellschaft, 1971.535 p.

22. Helfferich F. Ion exchange. New York: McGraw Hill, 1962. 520 p.

23. Кокотов Ю.А., Пасечник В.А. Равновесие и кинетика ионного обмена. Л.: Химия, 1979. 374 c. [Kokotov Y.A., Pasechnik V.A.. Equilibrium and kinetics of ion exchange. Leningrad: Khimiya, 1979. 374 p. (In Russ.)]

24. Pollard, J.H. A handbook of numerical and statistical techniques. Cambridge: Cambridge University Press, 1977. 342 p.

25. Harris D.C. Quantitative chemical analysis. New York: W.H. Freeman, 2007. 898 p.

26. Синицын Н.M., Буслаева Т.М. Химия комплексных галогенидов платиновых металлов. М.: Росвузнаука, 1992. 79 с. [Sinitsyn N.M., Buslaeva T.M. Chemistry of complex halides of platinum group metals. Moscow: Rosvuznauka, 1992. 79 p. (In Russ.)]

27. Reichenberg D. Ion exchange. A series of advances. J.A. Marinsky, Ed. Buffalo, New York: Mc Graw Hill, 1966. 104 p.

28. Griessbach R. Austauschadsorption in Theorie und Praxis. Berlin: Akademie-Verlag, 1957, $268 \mathrm{p}$.

29. Вольдман Г.М.. Зеликман А.Н. Теория гидрометаллургических процессов. М.: Интернет-Инжиниринг, 2003. 458 c. [Voldman G.M., Zelikman A.N. Theory of hydrometallurgical processes. Moscow: Internet-Engineering, 2003. 458 p. (In Russ.)] 